\title{
KEBERAGAMAN PENGGUNA RUANG PUBLIK PERMUKIMAN DI ATAS AIR BERKEPADATAN TINGGI
}

\author{
Hendri Fauzi, Johannes Parlindungan Siregar, Dian Kusuma Wardhani \\ Jurusan Perencanaan Wilayah dan Kota Fakultas Teknik Universitas Brawijaya \\ e-mail : $\underline{\text { hendrifauzi@yahoo.com }}$
}

\begin{abstract}
ABSTRAK
Kota Tarakan adalah wilayah yang paling berkembang di Kalimantan bagian utara dengan memiliki potensi yang besar sehingga memiliki daya tarik bagi masyarakat luar untuk masuk ke Kota Tarakan. Hal ini memiliki potensi sebagai kawasan dengan kepadatan yang tinggi, sehingga akan sulit dalam menyediakan ruang publik dengan kepentingan bersama yang dikarenakan terbatasnya ruang. Kegiatan yang dilakukan masyarakat mampu mendukung kegiatan sosial dan perilaku dengan beberapa aktivitas. Yang mampu membentuk ruang sosial yang digunakan secara bersama yang dikategorikan sebagai ruang publik yang mewadahi aktivitas tertentu dari masyarakat baik secara individu maupun kelompok, dengan usia maupun jenis kelamin. Tujuan dari penelitian ini adalah mengidentifikasi keberagaman pengguna berdasarkan tipologi ruang dan pola aktivitas dari ruang publik yang diamati. Penilaian dari keberagaman pengguna menggunakan Simpsons Diversity Index dengan data yang berasal dari observasi lapangan. Penelitian ini menjelaskan bahwa dengan kondisi kepadatan yang tinggi dengan jenis permukiman yang berada di atas air ditemukan bahwa pengguna ruang publik pada sub blok penelitian memiliki keberagaman dan tipologi ruang yang berbeda pada tiap sub bloknya.
\end{abstract}

Kata Kunci : Ruang publik, simpsons diversity index, keberagaman pengguna, tipologi ruang

\begin{abstract}
Tarakan City is the most developed region in northern Borneo with great potential that has a fascination for outsiders to enter Tarakan City. It has potential as a region with a high density, so it will be difficult to provide a public space with a common interest due to the limited space. Activities undertaken communities are able to support social activities and behaviors with some activity. Capable of forming a social space that is used together are categorized as public spaces that accommodate the specific activity of the community either individually or in groups, by age and gender. The purpose of this study is to identification the diversity of the user based on the typology of space and activity patterns of public space were observed. Assessment of the diversity of users using the Simpsons Diversity Index with data from observations. This study suggested that the high density conditions with the type of settlement that is in the water it was found that users of public space in the sub-blocks of different studies have diversity in each sub- tract.
\end{abstract}

Keywords: Public Space, simpsons diversity index, diversity of users, typology of space

\section{Pendahuluan}

Sebuah kota memiliki permasalahan yang berkaitan dengan pertumbuhan penduduk. Kepadatan tersebut akan mempengaruhi ketersediaan lahan yang diakibatkan kebutuhan akan suatu ruang. Padatnya bangunan rumah tinggal dalam 
kawasan permukiman tentunya sulit menyediakan fasilitas ruang terbuka sebagai ruang bersama (Burhanuddin,2010). Ruang bersama ini merupakan salah satu jenis ruang sosial yang dikategorikan sebagai ruang publik. Masyarakat harus memiliki hak untuk dengan mudah dapat mengakses ruang publik. Ruang publik berada di sekitar kita, yang merupakan bagian penting dari kehidupan sebuah perkotaan dimana jalan-jalan yang dilewati untuk bersekolah atau bekerja, tempat dimana anak-anak bermain, jalan-jalan dan duduk sejenak dari hiruk pikik kesibukan kehidupan sehari-hari. Dengan kata lain, ruang publik adalah ruang terbuka kita, dengan pusat rekreasi yang berada di luar ruangan (CABE, 2003). Keberhasilan suatu ruang publik sangat tergantung pada sejauh mana ruang publik tersebut dapat akomodatif terhadap kebutuhan masyarakat. Akomodatif terhadap siapapun penggunanya: tua muda, besar kecil, wanita pria, dan sebagainya (Kurniawati, 2005).

Jahn Gehl (1987), dalam Life Between Building, aktivitas sosial merupakan aktivitas yang tergantung dari kehadiran orang lain dalam ruang publik dan merupakan bentuk kontak sosial. Ruang publik diharapkan mampu merespon masyarakat untuk berinteraksi sehingga mampu menciptakan aktivitas sosial sehingga terjadi interaksi sosial antar masyarakat. Interaksis sosial merupakan syarat utama terjadinya berbagai bentuk aktivitas sosial yang menunjukkan adanya hubungan sosial yang dinamis.

Untuk itu, makalah ini disusun berdasarkan hasil penelitian sebelumnya dan gambaran kegiatan aktivitas sosial masyarakat Kelurahan Selumit Pantai Kota Tarakan yang memiliki karakter permukiman yang berada di atas air. Tujuan dari penelitian ini adalah mendeskripsikan tipologi ruang dan pola aktivitas ruang publik dengan pengamatan menggunakan behaviour map sehingga dapat digunakan sebagai menilai keberagaman pengguna ruang.

\section{Bahan dan Metode}

Penelitian ini membagi menjadi 17 sub blok berdasarkan batas administrasi dan jalan lingkungan. Gambar 1 menunjukkan wilayah penelitian yang akan memudahkan dalam melaksanakan proses observasi lapangan. Penelitian ini merupakan jenis penelitian observasi lapangan untuk mendapatkan data tipologi aktivitas dan pola ruang publik yang menggunakan behaviour map. Pengamatan dilakukan selama hari kerja dua hari dan satu hari pengamatan hari libur dengan waktu dibagi menjadi empat waktu dalam satu hari yaitu pagi pukul 06.30-07.00, siang pukul 12.30-13.00, sore pukul 16.00-16.30 dan malam pukul 19.00-19.30. 


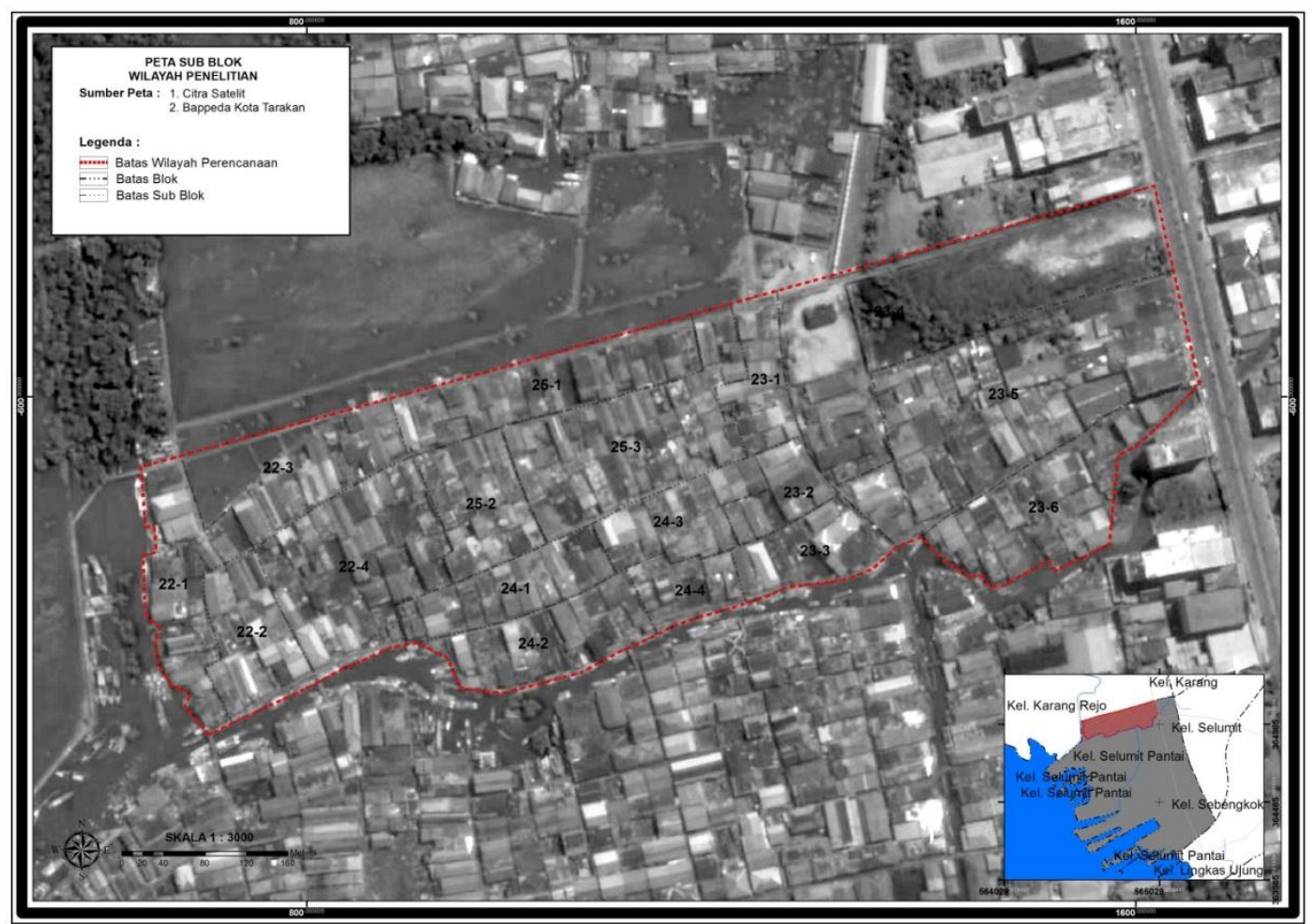

Gambar 1. Lokasi Kepadatan Tinggi Wilayah Perencanaan

\subsection{Teori Dasar}

Ruang dapat terbentuk karena adanya suatu aktivitas. Ruang yang terbentuk karena aktivitas bermasyarakat merupakan ruang sosial hasil dari kehidupan masyarakat. Keberadaan ruang bersama merupakan simbol dari masyarakat, terutama dalam suatu permukiman yang memiliki hubungan antar sesama masyarakat yang baik, ditandai dengan adanya kebersamaan. Ruang publik yang menarik akan selalu dikunjungi oleh masyarakat dengan berbagai perbedaan umur, jenis kelamin dan lain sebagainya dengan tingkatan kepentingan yang berlainan. Keberadaan aktivitas pada ruang luar dapat menjadi indikator kualitas ruang publik perkotaan (Gehl, 1987).Ruang publik yang baik harus memiliki tiga kriteria diantaranya meaningful, responsive, dan democratic (Carmona et al, 2003). Dengan adanya ketiga kriteria tersebut, akan mampu mendorong pengguna ruang publik yang beragam. Pria, wanita anak-anak dan orang tua memiliki persepsi yang berbeda terhadap ruang publik yang dapat mempengaruhi penggunaan ruang publik sehingga berbagai kegiatan dan keragaman dalam usia dan jenis kelamin mampu menunjukkan seberapa responsif ruang tersebut bagi pengguna dengan tujuannya (Mehta, 2007).

\subsection{Metode Analisis}

Analisis yang digunakan dalam penelitian ini adalah dengan analisis deskriptif eksploratif dan analisis evaluasi.

\section{A. Analisis Deskriptif Eksploratif}

Analisis deskriptif eksploratif bertujuan untuk mengetahui tipologi dan pola ruang publik yang terdapat pada ruang publik dengan kepadatan tinggi. Hal ini lebih menjabarkan kondisi dari tipologi ruang publik dan pola aktivitas yang terjadi dengan dilengkapi beberapa foto hasil observasi lapangan serta dilakukan pemetaan sebagai visualisasi spasial atau yang biasa disebut behaviour map. Untuk tipologi ruang publik 
berdasarkan fungsinya secara umum (Carmona, et al, 2008 : 62) ruang perkotaan terdiri dari ruang positif (ruang alami, ruang umum, ruang terbuka umum), ruang negatif (ruang pergerakan, ruang sevris, ruang sisa, ruang yang tidak jelas), ruang ambigu (ruang perpindahan, ruang publik 'privat', ruang privat 'publik', ruang conspiuous, ruang publik internal, ruang retail, ruang ketiga, ruang privat visibel, ruang penghubung, ruang pilihan) dan ruang privat ruang ambigu dan ruang privat (ruang terbuka privat, ruang privat eksternal). Sedangkan Zhang dan Lawson (2008) membagi pola aktivitas ruang publik terbagi menjadi beberapa klasifikasi aktivitas pada ruang publik klasifikasi adalah aktivitas proses, aktivitas fisik dan aktivitas transisi yang kemudian dari aktivitas tersebut dapat diketahui keberagaman pengguna dari ruang publik tersebut. Aktivitas proses adalah aktivitas yang dilakukan di antara dua aktivitas dengan tujuan yang jelas. Aktivitas ini berbentuk kegiatan pulang dan pergi yang bisa dilaksanakan dengan mempergunakan kendaraan atau berjalan kaki. Aktivitas fisik adalah aktivitas yang terjadi ketika dua orang atau lebih melakukan interaksi dan aktivitas transisi berupa aktivitas yang dilakukan tanpa tujuan yang jelas dan biasanya dilakukan secara individual.

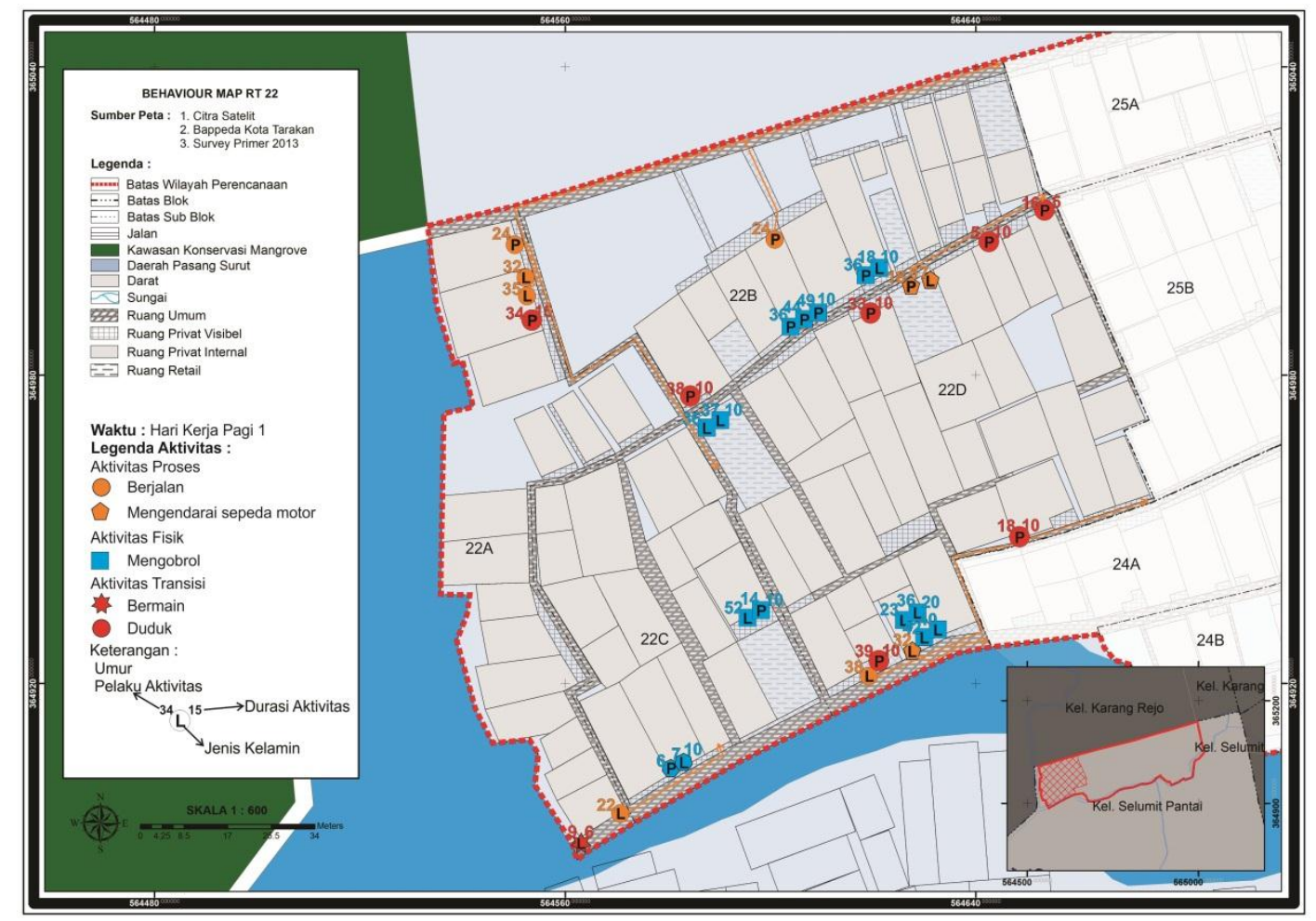

Gambar 2. Peta Behaviour Map RT 22 


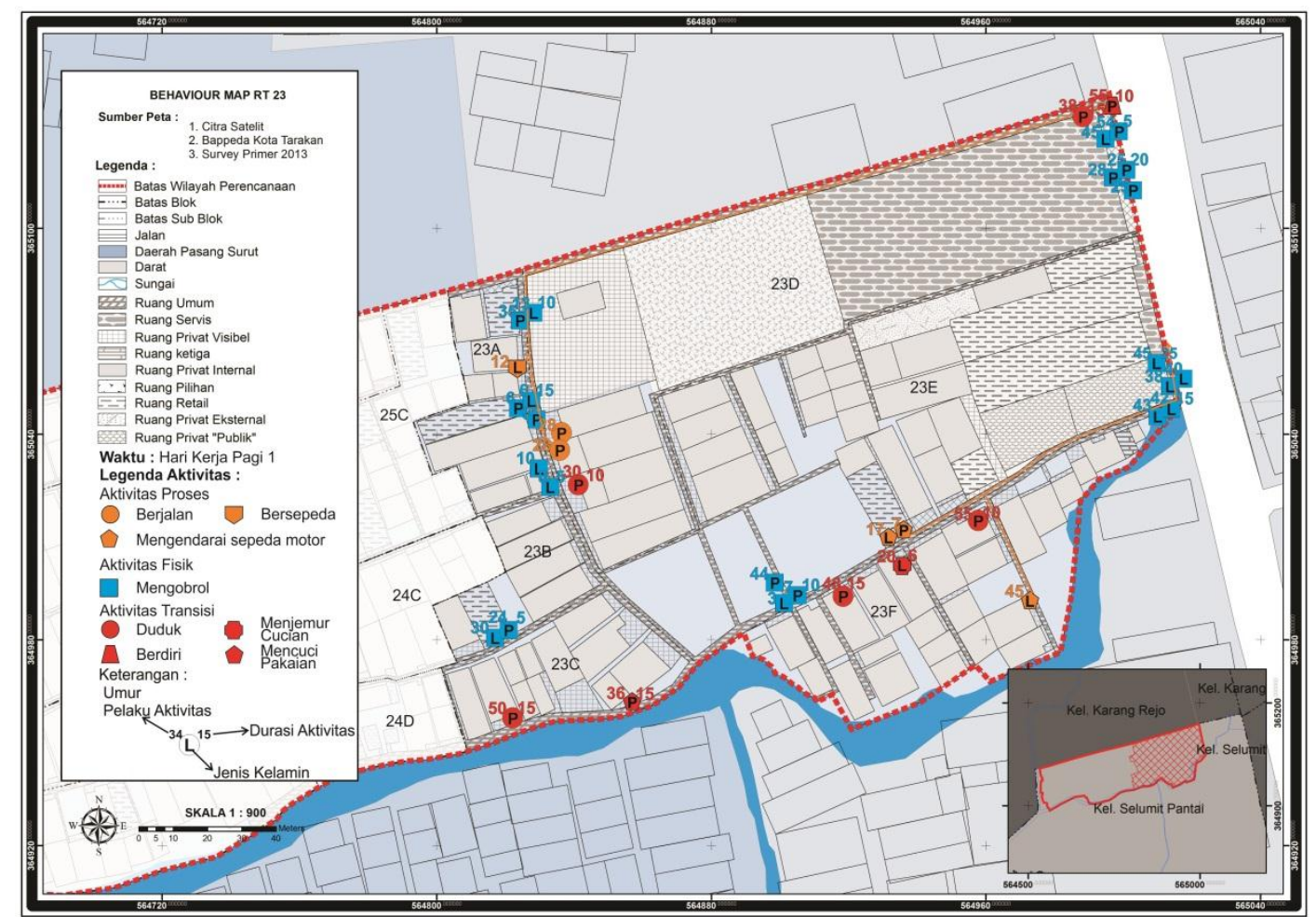

Gambar 3. Peta Behaviour Map RT 23

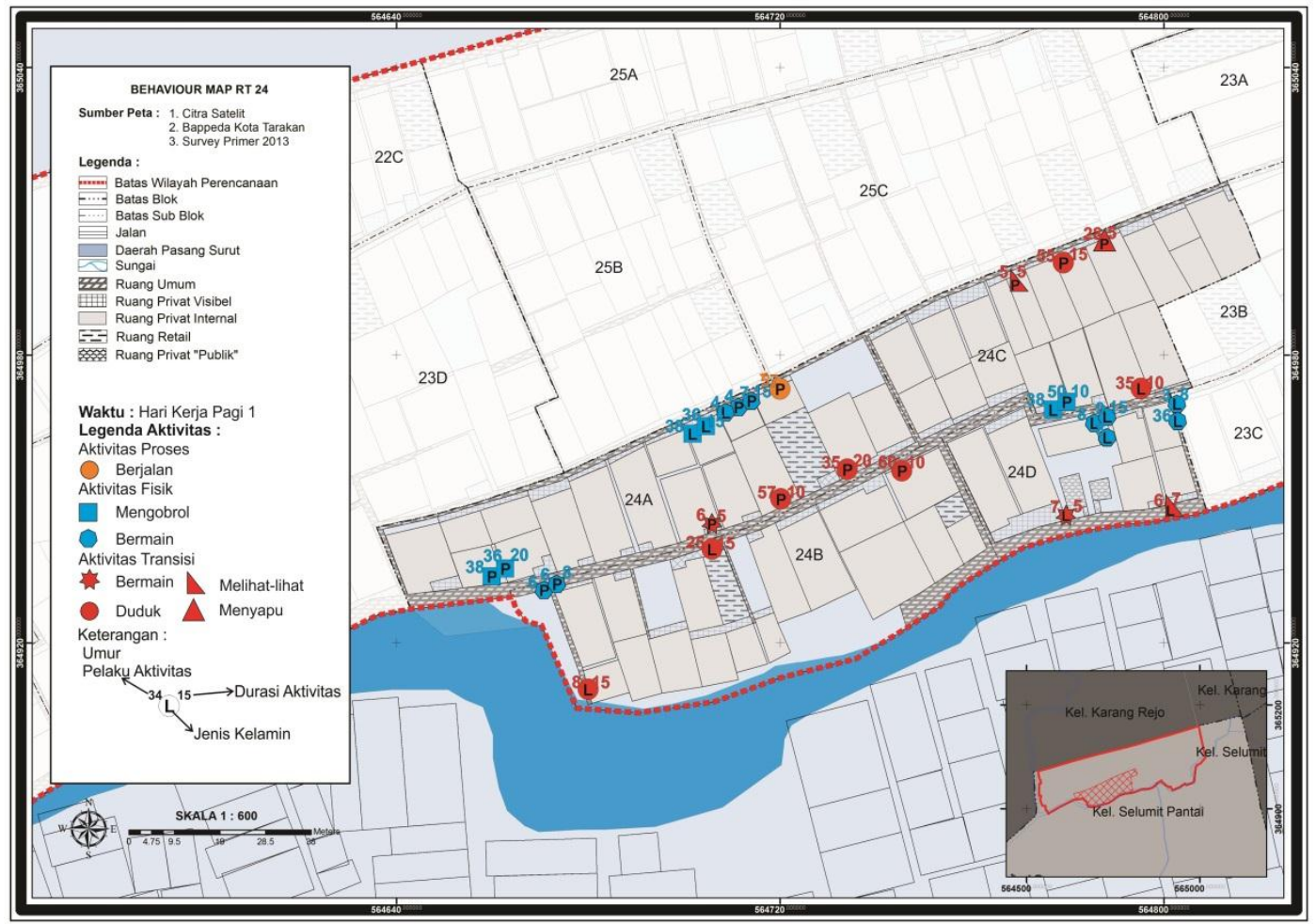

Gambar 4. Peta Behaviour Map RT 24 


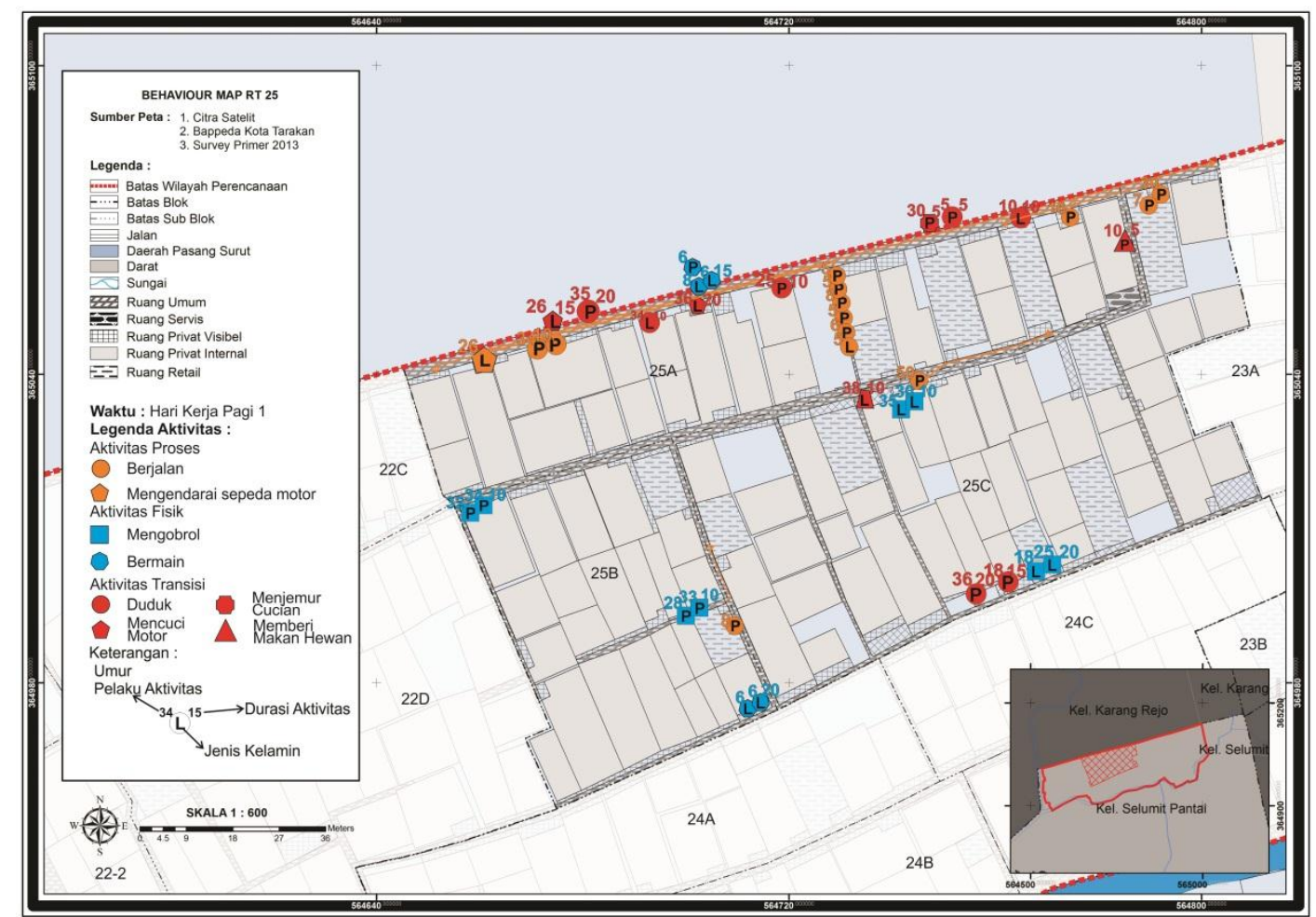

Gambar 5. Peta Behaviour Map RT 25

\section{B. Analisis Evaluatif}

Analisis evaluatif merupakan analisis yang bertujuan untuk mengevaluasi nilai dari keberagaman pengguna dari ruang publik. Keberagaman pengguna dalam penelitian ini merupakan salah satu variabel dalam mengetahui kualitas ruang publik yang berdasarkan pada tipologi ruang publik dan pola ruang publik yang diusulkan oleh Mehta (2007). Keberagaman pengguna ini diukur berdasarkan variasi pengguna berdasarkan usia dan jenis kelamin. Untuk penentuan umurnya adalah usia $0-4,5-12$, 13-18, 19-40, 41-65, dan 65+.

Dari keseluruhan variabel, jumlah orang yang terlibat dalam kelompok dengan aktivitasnya ini diberi nilai atau skor masing-masing 1 . Untuk mengetahui keberagaman pengguna ini, diggunakan Simpson's Diversity Index dengan berdasarkan usia dan jenis kelamin pengguna ruang dengan beberapa aktivitas yang dilakukan oleh masyarakat pada ruang publik. Adapun untuk rumus Simpson's Diversity Index yang digunakan adalah menggunakan sebagai berikut:

$$
\mathrm{D}=1-\left(\frac{\sum n(n-1)}{N(N-1)}\right)
$$

Keterangan:

$\mathrm{D}=$ Simpson's Index

$\mathrm{n}=$ jumlah aktivitas yang dilaksanakan

$\mathrm{N}=$ jumlah keseluruhan aktivitas yang dilaksanakan

Sumber : http://www.countrysideinfo.co.uk/simpsons.htm 


\section{Hasil dan Pembahasan}

\subsection{Analisis Deskriptif Eksploratif}

\subsubsection{Tipologi ruang publik}

Tipologi ruang publik pada permukiman wilayah penelitian memiliki beragam ruang. Adapun tipologi ruang publik wilayah penelitian yang didapatkan berdasarkan penelitian sebelumnyadapat diklasifikasikan sebagai berikut:

1. Ruang positif adalah ruang yang dapat dimanfaatkan untuk kegiatan-kegiatan yang sifatnya positif. Adapun dalam sub blok penelitian yang termasuk pada ruang positif adalah berikut ini:

Ruang umum, yang dikarenakan ruang ini memiliki fungsi ruang yang selalu terbuka dan tersedia bagi semua orang dan dapat dipergunakan untuk beragam fungsi. Bentuk dari ruang ini antara lain jalan lingkungan yang kecil di depan rumah, dimana jalan ini sering dilalui oleh masyarakat baik menggunakan kendaraan bermotor ataupun berjalan kaki. Selain itu, masyarakat sering menggunakannya sebagai tempat berinteraksi antar tetangga dengan duduk-duduk di pinggir jalan serta anak-anak bermain. Ruang umum ini memiliki luasan total sebesar $5948 \mathrm{~m}^{2}$.

2. Ruang negatif adalah ruang yang berupa ruang publik yang dapat tidak dimanfaatkan bagi kegiatan publik secara optimal karena memiliki fungsi yang tidak sesuai dengan kenyamanan dan keamanan aktivitas sosial. Adapun dalam sub blok penelitian yang termasuk pada ruang negatif adalah berikut ini:

Ruang service memiliki luasan total sebesar $3426 \mathrm{~m}^{2}$. Ruang ini hanya terdapat dibeberapa sub blok saja. Penentuan tipologi ini dikarenakan ruang ini terdapat dominasi aktivitas servis modern, seperti tempat parkir dan ruang bongkar muat. Kondisi ruang ini memang sering digunakan sebagai tempat parkir kendaraan seperti angkutan umum, truk dan kendaraan bermotor lainnya serta merupakan tempat parkir bagi guna lahan perdagangan.

3. Ruang ambigu adalah ruang yang dipergunakan untuk aktivitas peralihan dari kegiatan utama masyarakat yang biasanya berbentuk seperti ruang bersantai. Adapun dalam sub blok penelitian yang termasuk pada ruang ambigu adalah berikut ini.

a. Ruang privat visibel yang dikarenakan berupa ruang privat yang memiliki akses visual secara publik, yaitu halaman depan rumah dari permukiman. Ruang privat visibel ini memiliki luasan total sebesar $4584 \mathrm{~m}^{2}$.

b. Ruang ketiga berupa ruang semi publik yang berfungsi sebagai tempat pertemuan dan sosialisasi baik dikelola secara publik maupun privat yaitu berupa pos keamanan. Ruang ketiga ini memiliki luasan total sebesar $25 \mathrm{~m}^{2}$.

c. Ruang retail berupa ruang yang dimiliki secara privat tetapi memiliki akses publik yang lebih besar, pada wilayah penelitian berupa toko kelontong. Ruang retail ini memiliki luasan total sebesar $4729 \mathrm{~m}^{2}$.

d. Ruang pilihan berupa ruang yang pemanfaatannya dipilih oleh kelompok tertentu berdasarkan usia, aktivitas dan lain sebagainya, misalnya lapangan olahraga untuk bermain bola dan pada waktu tertentu seperti 17 Agustus dijadikan sebagai tempat perlombaan. Ruang pilihan ini memiliki luasan total sebesar $2371 \mathrm{~m}^{2}$.

e. Ruang privat 'publik'. Berupa ruang yang dimiliki atau dikelola secara publik tetapi dipergunakan secara terbatas oleh sekelompok orang, yaitu hotel dan stasiun pemadam kebakaran mini. Ruang privat "publik" memiliki luasan total sebesar $876 \mathrm{~m}^{2}$. 
4. Ruang privat ruang yang dimiliki secara privat oleh warga yang biasanya berbentuk ruang terbuka privat, halaman rumah dan ruang di dalam bangunan. Adapun dalam sub blok penelitian yang termasuk pada ruang privat adalah berikut ini.

Ruang privat internal yang dikarenakan bangunan tersebut dimiliki dan dikelola secara privat. Ruang privat internal di wilayah penelitian berupa permukiman yang sebagian besar merupakan rumah panggung yang memiliki luasan total sebesar $31948 \mathrm{~m}^{2}$.

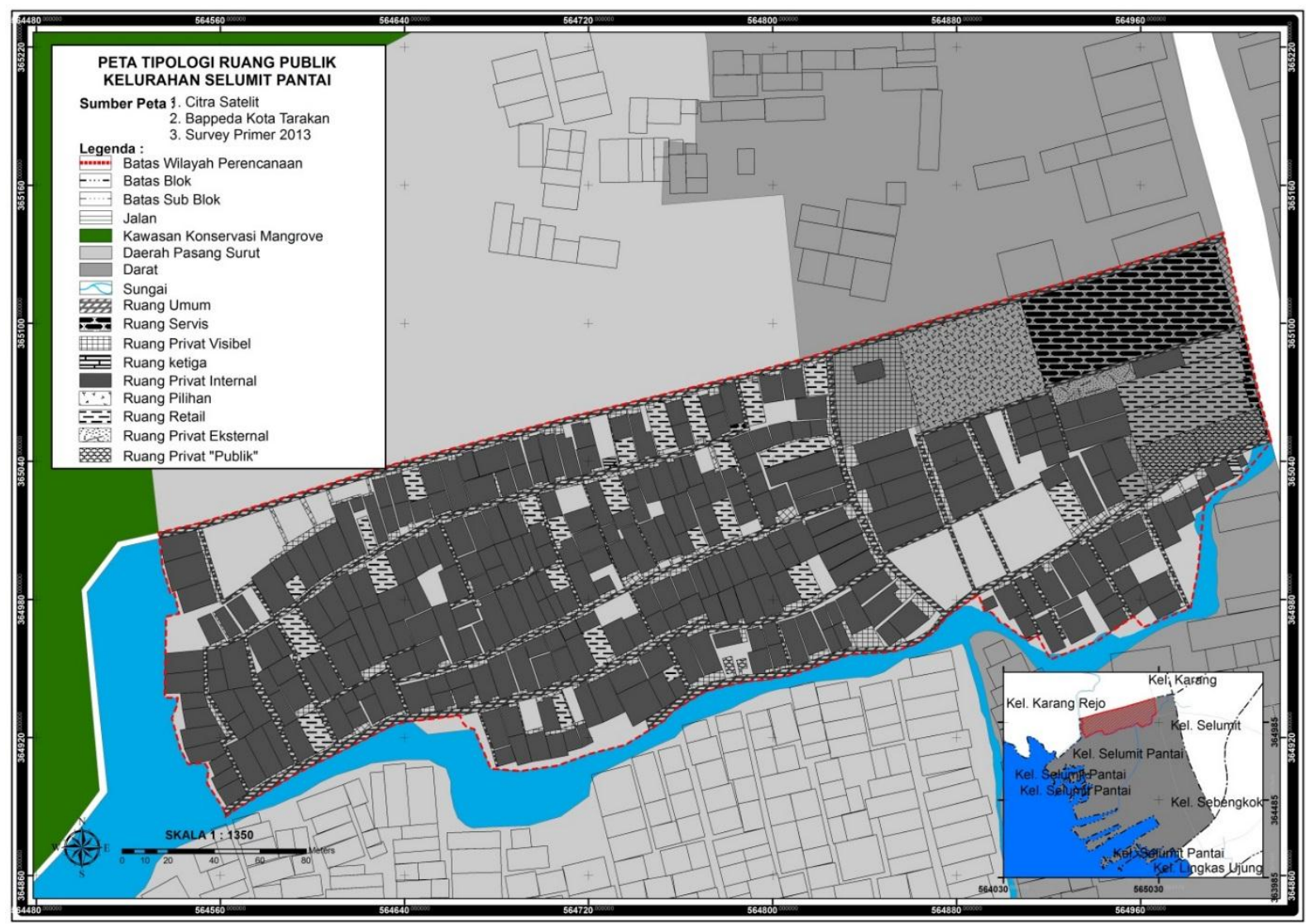

Gambar 6. Tipologi Ruang Publik Wilayah Penelitian

\section{a. Pola Aktivitas}

Berdasarkan hasil dari proses observasi aktivitas pada masing-masing sub blok yang dilihat berdasarkan pada rata-rata data jumlah dari aktivitas yang dilakukan masyarakat pada masing-masing ruang. Dari keseluruhan sub blok, aktivitas proses yang memiliki rata-rata jumlah orang terbesar dalam tiap aktivitas proses adalah sub blok 24B ( $\mathrm{n}=63)$ dengan aktivitas berupa berjalan dan bersepeda. Untuk aktivitas fisik yang memiliki rata-rata jumlah orang terbesar dalam tiap aktivitas fisik adalah sub blok 22D $(n=158)$ dengan aktivitas berupa mengobrol, bermain dengan teman dan bekerja serta sub blok 25A dan 25C $(n=77)$ memiliki rata-rata jumlah orang terbesar dalam aktivitas transisi memiliki aktivitas berupa bekerja, berdiri, bermain, duduk, memperbaiki kendaraan, kegiatan rumah tangga, dan menelepon. Berikut merupakan tabel dari aktivitas yang terdapat pada setiap sub blok penelitian. 
Tabel 1. Aktivitas pada Seluruh Sub Blok

\begin{tabular}{|c|c|c|c|c|c|c|c|c|c|c|c|c|c|c|c|c|c|}
\hline \multirow{2}{*}{$\begin{array}{c}\text { Jenis } \\
\text { Aktivitas }\end{array}$} & \multicolumn{17}{|c|}{ Sub Blok } \\
\hline & 22A & 22B & 22C & 22D & 23A & 23B & 23C & 23D & 23E & 23F & 24A & 24B & 24C & 24D & 25A & 25B & 25C \\
\hline \multicolumn{18}{|c|}{ Aktivitas Proses } \\
\hline Berjalan & 13 & 13 & 27 & 19 & 34 & 5 & 4 & 49 & 16 & 6 & 6 & 1 & 2 & 1 & 35 & 11 & 29 \\
\hline Bersepeda & 9 & - & 11 & 2 & 7 & - & - & 7 & 2 & - & - & - & - & - & 13 & 2 & 6 \\
\hline \multicolumn{18}{|c|}{ Aktivitas Fisik } \\
\hline Mengobrol & 12 & 32 & 77 & 99 & 28 & 30 & 52 & 41 & 38 & 72 & 93 & 20 & 65 & 32 & 41 & 32 & 110 \\
\hline $\begin{array}{l}\text { Bermain } \\
\text { dengan teman }\end{array}$ & 12 & 41 & 30 & 59 & 16 & 19 & 20 & 67 & 90 & 11 & 43 & 43 & 21 & 34 & 49 & 21 & 23 \\
\hline Bekerja & - & - & - & - & 2 & - & - & - & - & - & - & - & - & - & - & - & - \\
\hline \multicolumn{18}{|c|}{ Aktivitas Transisi } \\
\hline Bekerja & - & - & - & - & 1 & - & 1 & - & - & - & - & 1 & 1 & - & 2 & - & - \\
\hline Berdiri & 1 & - & 3 & 4 & 4 & 2 & 1 & 3 & 3 & 3 & 1 & - & 2 & 2 & 3 & 2 & 6 \\
\hline Bermain & 2 & - & 1 & 1 & 1 & - & - & 1 & 1 & 2 & 1 & - & - & 1 & 2 & - & 1 \\
\hline Duduk & 7 & 5 & 8 & 19 & 9 & 5 & 8 & 15 & 11 & 14 & 9 & 6 & 9 & 3 & 18 & 5 & 23 \\
\hline Melihat-lihat & 1 & - & - & 1 & - & - & - & - & - & 1 & - & 1 & - & 1 & - & - & - \\
\hline $\begin{array}{l}\text { Memberi } \\
\text { makan hewan } \\
\text { peliharaan }\end{array}$ & - & - & - & - & - & - & - & - & - & 1 & - & - & 1 & - & - & - & - \\
\hline $\begin{array}{l}\text { Memperbaiki } \\
\text { kendaraan }\end{array}$ & - & - & - & - & - & - & - & 1 & - & - & 1 & - & - & - & - & - & 1 \\
\hline $\begin{array}{l}\text { Kegiatan } \\
\text { rumah tangga }\end{array}$ & 2 & 1 & 1 & 8 & 2 & 1 & 5 & 2 & 2 & 10 & 5 & 2 & 5 & 3 & 11 & - & 4 \\
\hline Menelepon & - & - & 1 & - & - & - & - & - & 3 & - & 1 & - & 1 & - & - & - & 1 \\
\hline Menjaga anak & - & - & - & - & - & - & 1 & - & 2 & - & 3 & - & - & - & - & - & - \\
\hline
\end{tabular}




\subsection{Analisis Evaluatif}

Keberagaman pengguna dimanfaatkan untuk melihat karekteristik orang yang terlibat dalam kegiatan di luar ruangan. Dari hasil penelitian sebelumnya di dapatkan besaran nilai sebaran pengguna ruang seperti berikut ini.

Tabel 2. Sebaran Pengguna Ruang

\begin{tabular}{|c|c|c|c|c|c|c|c|c|c|c|c|c|c|c|c|c|c|}
\hline \multirow{2}{*}{$\begin{array}{c}\text { Jenis } \\
\text { Aktivitas }\end{array}$} & \multicolumn{17}{|c|}{ Sub Blok } \\
\hline & $22 \mathrm{~A}$ & 22B & $22 \mathrm{C}$ & 22D & $23 A$ & 23B & $23 \mathrm{C}$ & 23D & $23 E$ & $23 F$ & $24 A$ & $24 B$ & $24 \mathrm{C}$ & 24D & $25 A$ & 25B & $25 \mathrm{C}$ \\
\hline \multicolumn{18}{|c|}{ Pria } \\
\hline $0-4$ & - & 3 & - & 7 & 2 & 1 & 2 & 12 & 3 & 2 & 4 & 1 & 2 & 1 & 4 & 3 & 5 \\
\hline $5-12$ & 20 & 29 & 24 & 39 & 22 & 11 & 6 & 44 & 59 & 9 & 18 & 40 & 15 & 26 & 47 & 10 & 31 \\
\hline $13-18$ & 1 & 1 & 10 & 5 & 6 & 6 & 9 & 9 & 7 & 8 & 5 & 3 & 9 & 7 & 4 & 2 & 7 \\
\hline $19-40$ & 23 & 22 & 38 & 32 & 27 & 9 & 21 & 46 & 26 & 57 & 34 & 15 & 17 & 5 & 40 & 18 & 69 \\
\hline $41-65$ & - & 6 & - & 11 & 2 & 1 & 4 & 5 & 6 & 13 & 4 & 4 & 4 & 3 & 4 & - & 6 \\
\hline $65+$ & - & - & - & - & - & - & - & - & - & - & - & - & - & - & - & - & - \\
\hline \multicolumn{18}{|c|}{ Wanita } \\
\hline $0-4$ & 1 & 6 & 7 & 3 & - & 3 & 5 & 5 & 3 & 1 & 5 & - & 5 & 1 & 7 & 1 & - \\
\hline $5-12$ & 6 & 14 & 28 & 44 & 11 & 8 & 9 & 21 & 27 & 1 & 29 & 5 & 14 & 11 & 19 & 15 & 8 \\
\hline $13-18$ & - & 2 & 8 & 11 & 6 & 2 & 4 & 11 & 4 & - & 1 & 2 & 8 & 2 & 8 & 1 & 19 \\
\hline $19-40$ & 8 & 7 & 38 & 49 & 26 & 21 & 22 & 26 & 29 & 21 & 59 & 6 & 30 & 17 & 36 & 22 & 42 \\
\hline $41-65$ & 1 & 2 & 6 & 11 & 2 & - & 10 & 7 & 4 & 8 & 4 & 3 & 3 & 4 & 5 & 1 & 17 \\
\hline $65+$ & - & - & - & - & - & - & - & - & - & - & - & - & - & - & - & - & - \\
\hline
\end{tabular}

Dari sebaran data tersebut dilakukan perhitungan keberagaman pengguna dari ruang publik tiap sub blok dengan memiliki nilai indeks seperti berikut ini.

Tabel 3. Keberagaman Pengguna

\begin{tabular}{|c|c|c|c|c|c|c|}
\hline \multirow[b]{2}{*}{ Sub Blok } & \multicolumn{4}{|c|}{ Keberagaman Pengguna } & \multirow[b]{2}{*}{ D } & \multirow[b]{2}{*}{ 1-D } \\
\hline & Total (n) & $(n-1)$ & $n(n-1)$ & $\begin{array}{c}\text { Total } \\
n(n-1)\end{array}$ & & \\
\hline $22 \mathrm{~A}$ & 60 & 59 & 3540 & 972 & 0,275 & 0,725 \\
\hline $22 \mathrm{~B}$ & 92 & 91 & 8372 & 1568 & 0,187 & 0,813 \\
\hline $22 \mathrm{C}$ & 159 & 158 & 25122 & 4338 & 0,173 & 0,827 \\
\hline $22 \mathrm{D}$ & 212 & 211 & 44732 & 7116 & 0,159 & 0,841 \\
\hline $23 \mathrm{~A}$ & 104 & 103 & 10712 & 1990 & 0,186 & 0,814 \\
\hline $23 \mathrm{~B}$ & 62 & 61 & 3782 & 696 & 0,184 & 0,816 \\
\hline $23 \mathrm{C}$ & 92 & 91 & 8372 & 1192 & 0,142 & 0,858 \\
\hline 23D & 186 & 185 & 34410 & 5428 & 0,158 & 0,842 \\
\hline $23 E$ & 168 & 167 & 28056 & 5694 & 0,203 & 0,797 \\
\hline $23 \mathrm{~F}$ & 120 & 119 & 1428 & 5532 & 0,387 & 0,613 \\
\hline $24 \mathrm{~A}$ & 163 & 162 & 26406 & 5738 & 0,217 & 0,783 \\
\hline $24 \mathrm{~B}$ & 79 & 78 & 6162 & 1846 & 0,300 & 0,700 \\
\hline $24 \mathrm{C}$ & 107 & 106 & 11342 & 1702 & 0,150 & 0,850 \\
\hline $24 \mathrm{D}$ & 77 & 76 & 5852 & 1114 & 0,190 & 0,810 \\
\hline $25 \mathrm{~A}$ & 174 & 173 & 30102 & 5478 & 0,182 & 0,818 \\
\hline $25 B$ & 73 & 72 & 5256 & 1076 & 0,205 & 0,795 \\
\hline $25 \mathrm{C}$ & 204 & 203 & 41412 & 8106 & 0,196 & 0,804 \\
\hline
\end{tabular}

Nilai indeks keberagaman pengguna memiliki rentang nilai dari 0,858 hingga 0,613 dimana sub blok yang tertinggi terdapat pada sub blok $23 \mathrm{C}$ dengan nilai 0,858 , sedangkan nilai indeks keberagaman pengguna yang terendah terdapat pada beberapa sub blok 23F dengan nilai 0,613. Nilai indeks keberagaman pengguna memiliki skala 0-1 dimana nilai yang mendekati 1 merupakan nilai maksimum atau sempurna sehingga untuk nilai 0,858 pada sub blok 23C merupakan nilai yang baik karena diantara sub blok yang lainnya, sub blok ini yang paling mendekati angka 1 . Nilai ini mampu 
menggambarkan bahwa sub blok ini memiliki keberagaman pengguna dari tiap jenjang usia dan jenis kelamin tanpa ada usia yang dominan dalam melaksanakan aktivitas.

- Sub blok tertinggi

Sub blok 23C memiliki nilai tertinggi dalam keberagaman pengguna dengan nilai 0,858 . Hal ini memperlihatkan bahwa data dari hasil pengamatan mampu menunjukkan bahwa sub blok 23C memiliki keberagaman pengguna dari tiap jenjang usia. Sehingga ruang publik pada sub blok 23C memiliki jumlah pengguna ruang yang beragam dari tiap jenjang usia. Sub blok 23C memiliki keberagaman usia pengguna ruang yang merata atau tidak ada usia yang dominan dalam melaksanakan aktivitas. Kelompok usia pengguna ruang ini adalah usia 0-4 tahun hingga 41-65 tahun untuk pria maupun wanita. Pada sub blok 23C memiliki tipologi ruang diantaranya adalah ruang positif yang berupa ruang umum dengan luasan $660 \mathrm{~m}^{2}$. Bentuk dari ruang ini antara lain jalan lingkungan yang kecil di depan rumah, dimana jalan ini sering dilalui oleh masyarakat baik menggunakan kendaraan bermotor ataupun berjalan kaki. Selain itu, masyarakat sering menggunakannya sebagai tempat berinteraksi antar tetangga dengan duduk-duduk di pinggir jalan serta anak-anak bermain. Selain itu terdapat ruang ambigu yang berupa ruang privat visibel dengan luasan $285 \mathrm{~m}^{2}$ dengan jenis ruang yaitu halaman depan rumah dari permukiman. Selain itu adalah ruang privat internal dengan luasan $1138 \mathrm{~m}^{2}$ yang berupa bangunan yang dimiliki dan dikelola secara privat. Gambar 7 memperlihatkan beberapa aktivitas masyarakat dalam melakukan aktivitas pada sub blok 23C.

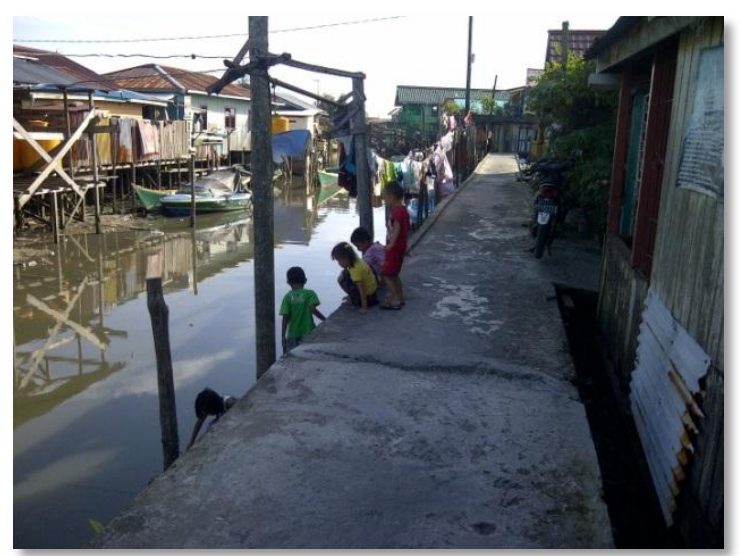

Gambar 7. Kondisi Sub Blok 23C

- Sub blok terendah

Sub blok 23F memiliki nilai terendah dari seluruh sub blok dengan nilai 0,613. Pada sub blok 23F yang memiliki nilai indeks terendah berarti memiliki keberagaman pengguna yang tidak merata sehingga keberagaman pengguna yang terjadi di dalamnya terdapat dominan usia bagi masyarakat yang berdasarkan hasil pengamatan adalah pada usia 19-40 dengan jenis kelamin pria. Kelompok usia pengguna ruang ini adalah usia 0-4 tahun hingga 41-65 tahun untuk pria dan 0-4 tahun hingga 41-65 tahun tanpa ada pengguna ruang dengan kelompok usia 13-18 tahun maupun wanita di sub blok tersebut. Pada sub blok 23F memiliki tipologi ruang diantaranya adalah ruang positif yang berupa ruang umum dengan luasan $424 \mathrm{~m}^{2}$. Bentuk dari ruang ini antara lain jalan lingkungan yang kecil di depan rumah, dimana jalan ini sering dilalui oleh masyarakat baik menggunakan kendaraan bermotor ataupun berjalan kaki. Ruang banyak dilalui masyarakat permukiman ini karena merupakan salah satu jalan keluar dan masuk yang bersinggungan dengan jalan arteri primer. Selain itu, masyarakat sering 
menggunakannya sebagai tempat berinteraksi antar tetangga dengan duduk-duduk di pinggir jalan serta anak-anak bermain. Selain itu terdapat ruang ambigu yang berupa ruang privat visibel dengan luasan $236 \mathrm{~m}^{2}$ dengan jenis ruang yaitu halaman depan rumah dari permukiman dan ruang retail dengan luasan $33 \mathrm{~m}^{2}$, ruang ini dimiliki secara privat tetapi memiliki akses publik yang lebih besar, pada wilayah penelitian berupa toko kelontong. Selain itu adalah ruang privat internal dengan luasan $2562 \mathrm{~m}^{2}$ yang berupa bangunan yang dimiliki dan dikelola secara privat. Gambar 8 memperlihatkan beberapa aktivitas masyarakat dalam melakukan aktivitas pada sub blok $23 \mathrm{~F}$.

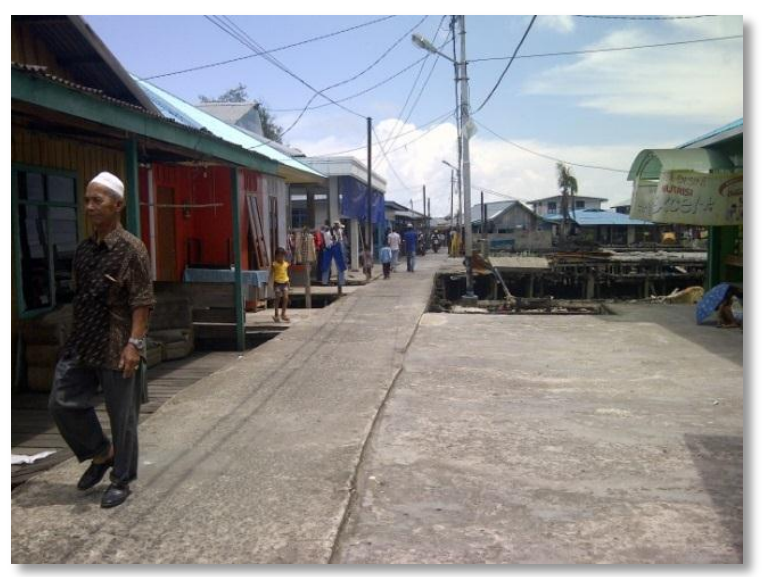

Gambar 8. Kondisi Sub Blok 23F

\subsection{Pembahasan}

Hasil penelitian ini menunjukkan keberagaman pengguna dari ruang publik dengan kondisi permukiman yang berkepadatan tinggi dengan jenis permukiman berada di atas air. Dengan kondisi tersebut, kelompok usia pengguna ruang memiliki keberagaman dengan usia 0-4 tahun hingga 41-65 tahun baik jenis kelamin pria maupun wanita. Aktivitas yang dilakukan masyarakat menggunakan ruang-ruang luar yang ada, diantaranya ruang positif, yang berupa ruang umum seperti jalan lingkungan dimana ruang ini digunakan untuk berjalan, bersepeda, mengobrol bahkan sebagai tempat bermain bagi anak-anak. Terdapat juga ruang negatif dalam sub blok penelitian yang berupa ruang ruang service seperti tempat parkir dan ruang bongkar muat. Selanjutnya adalah ruang ambigu yang berupa ruang privat visibel yang memiliki akses visual secara publik, yaitu halaman depan rumah dari permukiman, ruang ketiga yaitu berupa pos keamanan, ruang retail berupa toko kelontong, ruang pilihan berupa lapangan olahraga untuk bermain bola dan ruang privat 'publik' berupa hotel dan stasiun pemadam kebakaran mini. Keseluruhan dari ruang ambigu yang terdapat pada wilayah penelitian ini sering digunakan untuk mengobrol, bermain dan duduk-duduk oleh masyarakat. Serta terdapat juga ruang privat internal yang berupa bangunan yang dimiliki dan dikelola secara privat. Beberapa ruang yang ada di wilayah penelitian mampu mendukung aktivitas yang dilakukan oleh masyarakat.

Berdasarkan pada aktivitas yang dilakukan oleh masyarakat dengan keberagaman dari pengguna mampu menunjukkan bahwa ruang publik tersebut menarik untuk tempat beraktivitas dan berinteraksi. Berbeda dari pernyataan Burhanuddin, ternyata masyarakat dengan kepadatan permukiman yang tinggi, akan mudah dalam membentuk ruang bersama yang umumnya berupa teras rumah dan jalan lingkungan sekitar tempat tinggal mereka. Masyarakat menggunakan ruang tersebut 
untuk mengobrol dengan tetangga, tempat bermain anak, dan duduk-duduk. Adapun menurut PPS.Org, hasil dari penelitian ini wilayah penelitian permukiman di atas air mampu memenuhi kriteria yang harus dicapai dalam penggunaan ruang publik diantaranya banyak aktivitas publik yang dapat dilaksanakan oleh setiap orang untuk berpartisipasi, terdapat keseimbangan yang baik antara pria dan wanita, tidak dibatasi oleh usia, ruang dapat dipergunakan sepanjang hari, serta ruang kondusif untuk tempat berkumpul warga secara berkelompok dan menghindari adanya pemakaian ruang oleh warga secara tunggal.

\section{Kesimpulan}

Kesimpulan yang dapat ditarik dari penelitian ini adalah sebagai berikut:

1. Kondisi ruang publik di luar ruangan dengan wilayah penelitian pada permukiman di atas air berkepadatan tinggi dengan adanya keberagaman aktivitas mampu mewadahi aktivitas masyarakat seperti mengobrol dengan tetangga, tempat bermain anak, dan duduk-duduk.

2. Masyarakat dengan kepadatan permukiman yang tinggi, akan mudah dalam membentuk ruang bersama yang umumnya berupa teras rumah dan jalan lingkungan sekitar tempat tinggal mereka.

\section{Daftar Pustaka}

Anonim. Simpson's Diversty Index. http://www.countrysideinfo.co.uk/simpsons.htm

Burhanuddin. 2010. Karakteristik Teritorialitas Ruang Pada Permukiman Padat di Perkotaan. Jurnal Ruang Volume 2 Nomor 1.

CABE. 2003. The Value of Public Space - How high quality parks and public spaces create economic, social, and environmental value, CABE.

Creating Walkable Communities. (1998). Washington, D.C: Bicycle Federation of America Campaign to Make America Walkable.

Gehl, J. 1987. Life Between Buildings. Van Nostrand Reinhold Company, New York.

Kurniawati, Wakhida. (2005). Jurnal Penataan Ruang Publik berdasar Aspek Keamanan bagi Wanita, Fakultas Teknik. Universitas Diponegoro, Semarang.

Mehta. 2007. A Toolkit for Performance Measures of Public Space. Urban Design International. Vol 13, 67-69.

What Makes a Successful Place? PPS.Org.

Zhang dan Lawson. 2009. Meeting and Greeting: activities in public outdoor spaces outside high-density urban residental communities. Urban Design International (2009), volume 14, 4, 207-214. 